Biol. Stud. 2019: 13(2); 3-10 • DOI: https://doi.org/10.30970/sbi.1302.595

www.http://publications.Inu.edu.ua/journals/index.php/biology

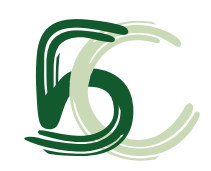

UDC: 577.352 .332

\title{
TWO ISOFORMS OF Trpm8 IN RAT VAS DEFERENS
}

\author{
K. Gulak ${ }^{1 *}$, A. Kondratskyi \\ ${ }^{1}$ Bogomoletz Institute of Physiology, NAS of Ukraine, 4, Bohomoletz St., 01601 Kyiv, Ukraine \\ 2 University of Lille, 42 Rue Paul Duez, 59000 Lille, France \\ *Corresponding author: e-mail: ksenia@biph.kiev.ua
}

Gulak K., Kondratskyi A. Two isoforms of Trpm8 in rat vas deferens. Studia Biologica, 2019: 13(2); 3-10 • DOI: https://doi.org/10.30970/sbi.1302.595

Trpm8 is a nonselective $\mathrm{Ca}^{2+}$-permeable ion channel activated by temperatures below $28^{\circ} \mathrm{C}$ and cooling chemical compounds such as menthol and icilin. Trpm8 is expressed in sensory neurons where it functions for temperature detection. However, Trpm8 is also expressed in various internal organs where temperature is stably higher than $36^{\circ} \mathrm{C}$, that is much higher than cool temperature needed for Trpm8 activation. This opens possible makes roles for Trpm8, such as nociception. Trpm8 mRNA is expressed in vas deferens (VD), a smooth muscle organ of male reproductive system. However, no Trpm8-mediated currents were previously registered in the myocytes. VD is located outside of testes, and it consists of smooth muscle tube covered by the epithelium. It actively contracts and transfers sperm from testes to ejaculatory ducts prior to ejaculation. Temperature in VD is stably high, thus, Trpm8 role there could be outside of cold detection. The objective of this study was to analyze Trpm8 mRNA and protein expression in rat VD, as well as splice variant analysis. Trpm8 mRNA expression in VD was confirmed with RT-PCR, and Trpm8 protein was detected by the Western-blot analysis. Additionally, we found that both mRNA and protein of shorter non-classical isoform, as well as canonical isoform of Trpm8 in VD. We isolated smooth muscle cells from VD and performed a multi-cell PCR. This technique makes possible non-myocytic mRNA detection that could be isolated from e.g. sensory neurons termini where Trpm 8 is expressed at much higher levels. Interestingly, in the isolated smooth muscle cells, no canonical Trpm8 transcript was found, though the non-classical isoform was present. We propose the shorter isoform could be formed as a result of alternative splicing. This would account for a difference in Trpm8 function in VD, i.e. no Trpm8-mediated currents registered in the myocytes. A shorter isoform could have a truncated $\mathrm{N}$-terminal domain, that is consistent with known human Trpm8 isoforms sM8-6 and sM8-18.

Keywords: Trpm8, cold receptor, splice variant, vas deferens, myocytes, gene expression

() 2019 K. Gulak et al.; Published by the Ivan Franko National University of Lviv on behalf of Біологічні Студії / Studia Biologica. This is an Open Access article distributed under the terms of the Creative Commons Attribution License (http://www.budapestopenaccessinitiative.org/ and Creative Commons Attribution 4.0 License), which permits unrestricted reuse, distribution, and reproduction in any medium, provided the original work is properly cited.

ISSN 1996-4536 (print) • ISSN 2311-0783 (on-line) • Біологічні Студії / Studia Biologica • 2019 • Том 13/№2 • С. 3-10 


\section{INTRODUCTION}

Trpm8 is a nonselective $\mathrm{Ca}^{2+}$-permeable cationic ion channel first discovered in 2001 as a prostate-specific transcript upregulated in prostate cancer [12]. Later, Trpm8 was classified as a TRP family member that is activated by cold temperatures between 10 $28^{\circ} \mathrm{C}[7,9]$, and cooling compounds such as menthol [10] and icilin [2, 13].

Trpm8 is expressed in sensory neurons where it functions for temperature detection. Trpm8 -/- knock-out mice lose the ability to sense cold and develop cold allodynia [9]. Trpm8 is also expressed in various internal organs where temperature remains stable around $37^{\circ} \mathrm{C}$ that is $10^{\circ} \mathrm{C}$ higher than a threshold point for Trpm8 activation. This proposes an additional temperature unrelated functions for Trpm8 [8]. For example, Trpm8 role in a nociception is a subject of numtrous studies. Surprisingly, some works showed Trpm8 lowers pain sensitivity during trauma, while other works highlighted active role of Trpm8 in a nociception [13].

Previously, we showed that Trpm8 transcript is present in smooth muscle cells of rat vas deferens (VD) [6]. VD is a part of male reproductive system. It consists of smooth muscle tube covered epithelium, and it actively contracts and transfers sperm from testes to ejaculatory ducts prior to ejaculation. In addition, menthol inhibits contractile activity of VD smooth muscle strips, while the magnitude of that effect differs for strips taken from epididymal and prostate parts of VD [6]. Our previous work showed an unexpected absence of Trpm8 related currents in the isolated smooth muscle cells of VD [5].

The objective of this study was to elucidate if Trpm8 protein is present in rat VD, well as analyze possible splice isoforms of Trpm8 mRNA.

\section{MATERIALS AND METHODS}

All experiments were performed on 3-month-old male Wistar rats (250-270 g). Experimental procedures were carried out in accordance with the International Convention of animals and the Law of Ukraine "On protection of animals from cruelty", protocol \#02/10 (08 February 2010) of the Bioethics Committee of Bogomoletz Institute of Physiology NAS of Ukraine.

Western-blot analysis. VD tissue was isolated, disposed of epithelial layer, divided into epididymal and prostate parts, and homogenized in a liquid nitrogen. Tissue powder was incubated in RIPA buffer $(25,0 \mathrm{mM}$ Tris- $\mathrm{HCl}$ pH 7.6, $150 \mathrm{mM} \mathrm{NaCl}, 1 \% \mathrm{TX} 100,1 \%$ Sodium deoxycholate, $0.1 \%$ SDS) during $45 \mathrm{~min}$ at $4{ }^{\circ} \mathrm{C}$. Samples were spun at $16000 \mathrm{~g}$ at $4{ }^{\circ} \mathrm{C}$ for $20 \mathrm{~min}$. Supernatant was used for standard $7.5 \%$ SDS-polyacrylamide gel electrophoresis. Protein samples were transferred into nitrocellulose membrane using semi-dry bloting. Primary antibodies were rabbit polyclonal anti-TRPM8 (Abcam, Cat. number ab3243), and rabbit anti-beta Actin antibody (Abcam, Cat. number ab8227), secondary antibody was Donkey anti-Rabbit lgG $(\mathrm{H}+\mathrm{L})$ Cross-Adsorbed (Thermo Fisher Scientific, Cat. number 31458). Signal was detected using standard electrochemiluminescence method on $X$-ray film. Membrane was additionally stained with Ponceau $S$ in order to detect protein ladder PageRuler ${ }^{\mathrm{TM}}$ Unstained Broad Range Protein Ladder (Thermo Fisher Scientific).

Reverse transcription PCR. Total RNA from VD was isolated using RNAzol ${ }^{\circledR}$ RT Kit (Sigma-Aldrich) according to manufacturer's manual. RNA concentration was calculated at 260 and $280 \mathrm{~nm}$ absorption spectrum (NanoDrop). Only samples with 260/280>1.6 absorption ratio were used in further experiments. First cDNA strand synthesis was

ISSN 1996-4536 (print) • ISSN 2311-0783 (on-line) • Біологічні Студії / Studia Biologica • 2019 • Том 13/№2 • C. 3-10 
performed using MMLV-reverse transcriptase Kit (Thermo Fisher Scientific), adding oligo-dT(18) and random hexamer primer, 50 pmol/reaction (Thermo Fisher Scientific).

Primer sequences for PCR were created with NCBI/Primer-BLAST. In order to avoid genome DNA amplification primers span an exon-exon junction. Beta actin was used as endogenous control. Primer sequences were as follows: Actb 5'-CTGTGTGGATTGGTGGCTCT-3' (forward), 5'-GCTCAGTAACAGTCCGCCTA-3' (reverse); Trpm8 5'-CCCCCACCTCCTCACGGTCA-3' (forward), 5'- AGGTCGGCAGACTCCCAGCG-3' (reverse). PCR conditions ran as follows: $94^{\circ} \mathrm{C}-45^{\prime}, 62^{\circ} \mathrm{C}-35^{\prime}, 72^{\circ} \mathrm{C}-45^{\prime}: 40$ cycles using T-CY thermocycler (CreaCon Technologies). Agarose gel electrophoresis was performed to visualize PCR results.

Multi-cell PCR. In order to exclude mRNA of non-myocytic origin, we performed the multi cell PCR. Cells were prepared as described previously [3]. Briefly, VD strips were cut into small segments, and treated with $0.2 \%$ Collagenase of Type XI (Sigma) in $\mathrm{Ca}^{2+}$-free physiological salt solution in the presence of $0.3 \%$ bovine serum albumin at $35^{\circ} \mathrm{C}$ for $30-40 \mathrm{~min}$. Single cells were obtained by gentle pipetting.

Freshly isolated VD myocytes ( $n=50$ cells) were identified under the microscope, and then captured one by one with a borosilicate glass micropipette (tip diameter 30 $50 \mu \mathrm{m}$ ), and transferred into a tube containing reverse transcription reaction mix. RTPCR was performed as previously described.

Restriction analysis. PCR products were cut from agarose gel. DNA of the isolated samples was purified using Silica Bead DNA Gel Extraction Kit (Thermo Fisher Scientific) and analyzed using Hindlll restriction enzyme. The results of restriction digestion were visualized in $2.5 \%$ agarose gel.

Data analysis. To test selected primer quality PCR digital mock test was performed with FastPCR 4.0.13 (PCR Team). Primer dimer formation ability was tested using PCR Primer Stats (The Sequence Manipulation Suite) [11].

Protein sequence corresponding to an appropriate DNA fragment was identified with Translate (SIB ExPASy Bioformatics Resources Portal) [1] using information from UniProt database, \#Q8R455 entry (rat Trpm8 protein).

\section{RESULTS AND DISCUSSION}

Trpm8 is expressed at protein level in myocytes isolated from rat VD. However, our previous work did not reveal typical for Trpm8 channel at detection using patch-clamp on VD myocytes [6]. The objective of this study was to elucidate protein and mRNA expression of Trpm8 in VD tissue, as well as a possible reason for absence of Trpm8 current in VD myocytes shown previously [5].

We found that although Trpm8 transcript was detected with RT-PCR, the resulting amplicons had two lengths: the expected full product with length of $213 \mathrm{bp}$ and truncated variant with a length of approximately $170 \mathrm{bp}$ (Fig. 1). Primers for PCR were selected in a way to exclude introns, specifically the reverse primer spans the junction between 11 th and 12th exons of $R$. norvegicus Trpm8 mRNA. A search using as a reference RefSec mRNA database for $R$. norvegicus Primer-BLAST additionally showed that $100 \%$ nucleotide specificity corresponded only to Trpm8 transcript and its variants X2X5 of the same size (213 bp). At unspecific PCR amplification and non-complementary base-pair formation, some additional amplicons could be observed: $22.5 \%$ unspecificity, i.e. formation of 5 of 20 non-complimentary base pairs on forward primer and 4/20 on reverse primer, amplification of Pou2f3 mRNA (296 bp) could be achieved; with $25 \%$

ISSN 1996-4536 (print) • ISSN 2311-0783 (on-line) • Біологічні Студії / Studia Biologica • 2019 • Том 13/№2 • С. 3-10 


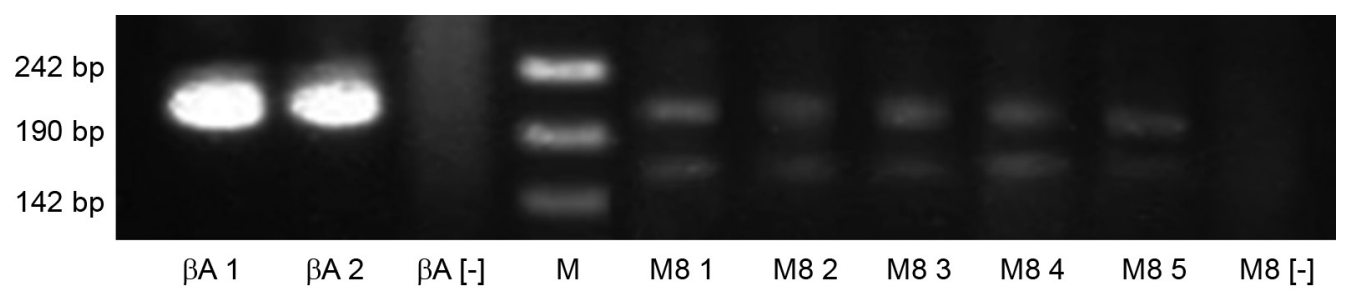

Fig. 1. Expression of Actb and Trpm 8 channel in total RNA isolated from vas deferens tissue. PCR-amplicons were examined by electrophoresis on a $2.5 \%$ agarose gel. Samples 1-2 ( $\beta A)$ : bands corresponding to mRNA for Actb. Samples 5-9 (M8): Trpm8, showed the expected amplicon (213 bp) and the shortened amplicon ( 170 pb). Samples 3 and 10: negative control. M: marker of DNA size

Рис. 1. Експресія Actb і Trpm8 у тотальній РНК, виділеній із тканини сім'явивідної протоки щурів. ПЛР-амплікони досліджували за допомогою електрофорезу на 2,5\% агарозному гелі. Доріжки 1-2 ( $\beta A)$ - смуги, що відповідають мРНК $\beta$-актину. Доріжки 5-9 (М8) - Trpm8, показали очікуваний амплікон (213bp) і вкорочений амплікон ( 170 pb). Доріжки 3 та 10 - негативний контроль. М - маркер розміру ДНК

unspecificity (5/20 non-complimentary base pairs on both primers) products can be formed of Supt5h (761 bp), Nsun5 (648 bp), and Kcnk3 (598 bp) mRNAs. All suggested unspecific products were larger than the observed truncated amplicon, and were absent in our studies. Moreover, such non-canonical base pair formation in $22.5 \%$ is unlikely to happen often, yet the truncated amplicon was observed systematically in VD tissue. An additional digital mock PCR with PCR Primer Stats showed no primer-dimerisation or hairpin formation with the selected primers. Thus, a formation of truncated amplicon comes not from unspecific primer binding, but is synthesysed from Trpm8 mRNA.

To test this, we performed additional analysis of specificity. Amplicons form first PCR were cut and purified from agarose gel and used as templates for secondary PCR. Obtained results showed that synthesis of both fragments is specific, i.e. fragments of $213 \mathrm{bp}$ and $170 \mathrm{bp}$ give rise a to amplicons of their own corresponding length (Fig. 2).

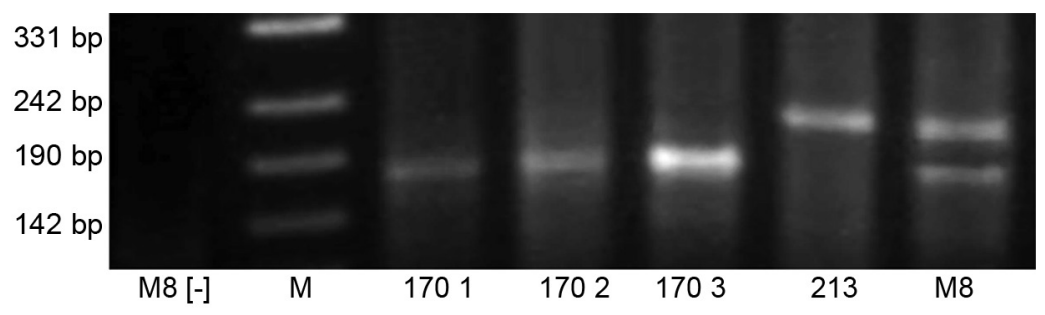

Fig. 2. Control of amplification of $213 \mathrm{bp}$ and $170 \mathrm{bp}$ Trpm8 products. PCR-amplicons corresponding to 213 and 170 bp Trpm8 products were cut from the agarose gel, DNA isolated using Silica Bead DNA Gel Extraction Kit and used in a second PCR reaction under the same conditions. Samples 3-5 (170): bands corresponding to $170 \mathrm{bp}$ product of Trpm8. Sample 6 (213) - to 213 bp product. Sample 7: positive control of the PCR reaction, using cDNA as matrix. Sample 1: negative control. M: marker of DNA size

Рис. 2. Контроль ампліконів 213 bp і 170 bp Trpm8. ПЛР-амплікони, що відповідають довжинам 213 та 170 bp Trpm8, вирізано з агарозного гелю, ДНК виділено за допомогою комплекту Silica Bead DNA Gel Extraction і використано у другій реакції ПЛР у тих же умовах. Доріжки 3-5 (170) - смуги, що відповідають 170 bp амплікону. Доріжка 6 (213) - 213 bр амплікону. Доріжка 7 - позитивний контроль реакції ПЛР із використанням кДНК як матриці. Доріжка 1 - негативний контроль. М - маркер розміру ДНК

ISSN 1996-4536 (print) • ISSN 2311-0783 (on-line) • Біологічні Студії / Studia Biologica • 2019 • Том 13/№2 • C. 3-10 
A restricion digestion of purified amplicons with HinDIII restrictase showed that $213 \mathrm{bp}$ amplicon was cut into two expected fragments (132 bp and $81 \mathrm{bp}$ ), while $170 \mathrm{bp}$ amplicon remainded undigested, thus, it does not have a restriction site in its nucleotide sequence (Fig. 3).

Fig. 3. Digestion by restriction enzyme of Trpm8 amplicons. PCR-amplicons corresponding to 213 and $170 \mathrm{bp}$ Trpm8 products were cut from the agarose gel, DNA isolated using Silica Bead DNA Gel Extraction Kit. The products were digested with HindIII restriction enzyme. Sample 2 (170): band corresponding to $170 \mathrm{bp}$ product of Trpm8 remained uncut; sample 3 (213): corresponding to 213 bp product, was cut as expected. M: marker of DNA size

Рис. 3. Рестрикційний аналіз ампліконів Trpm8. ПЛРамплікони, що відповідають продуктам Trpm8 у 213 і 170 п. о., вирізали з агарозного гелю, ДНК виділяли за допомогою комплекту Silica Bead DNA Gel Extraction. Зразки розрізали за допомогою ендонуклеази HindllI. Доріжка 2 (170) - смуга, що відповідає 170 bр продукту Trpm8 - залишилася нерозрізаною; смуга 3 (213) - до 213 bp, розрізана на очікувані фрагменти у 132 та $81 \mathrm{bp}$. М - маркер розміру ДНК

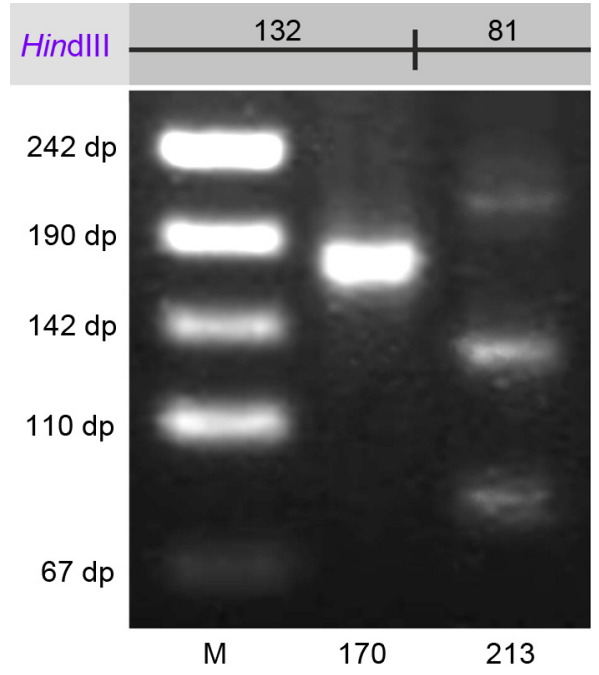

Previous PCR were performed on VD tissue that contains not only myocytes but also additional cell types such as nerve fibers or blood vessels. We also performed multi-cell PCR exclusively on myocytes. This was done by sampling 50 myocytes into the micropipette using patch-clamp pumping set-up and transferring them into RT-PCR tube. Interestingly, results showed absence of 213 bp product, but 170 bp amplicon was present (Fig. 4).

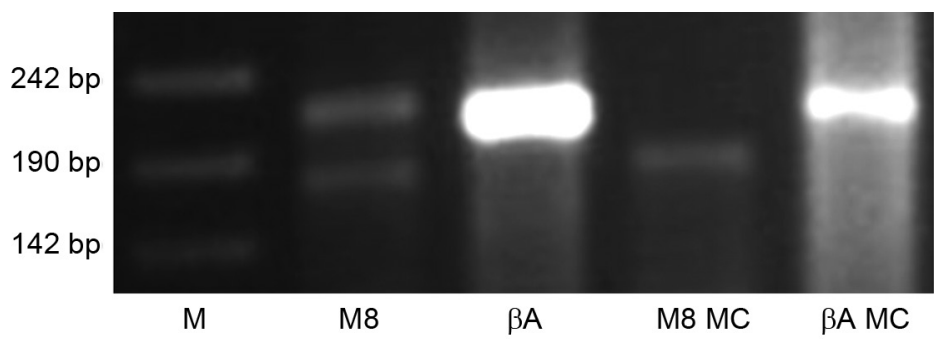

Fig. 4. The results of multi-cell RT-PCR demonstrating an expression of Trpm8 in individual smooth muscle cells and vas deferens tissue. Samples 1, 4 (M8): Trpm8, tissue and collected individual myocytes, respectively; samples 3, 5 (A): $\beta$-actin, tissue and collected individual myocytes, respectively. M: marker of DNA size

Рис. 4. Результати багатоклітинної ЗТ-ПЛР з експресією Trpm8 у окремих гладеньком'язових клітинах і тканині сім'явивідних проток. Доріжки 1, 4 (M8) - Trpm8 з тканини та з індивідуальних ГМК відповідно; доріжки 3, 5 (А) - Actb, з тканини та з індивідуальних ГМК відповідно. М - маркер розміру ДНК

Analysis based on the Western-blot hybridization of probes from VD tissue using Trpm8 antibodies showed presence of Trpm8 signal in selected tissue and in prostate positive control (Fig. 5). Interestingly, strips corresponding to VD tissue have two bands with Trmp8 antibody hybridization of different weight: $130.6 \mathrm{kDa}$ and a smaller band. In contrast, prostate tissue has only one band corresponding to $130.6 \mathrm{kDa}$ expected protein weight.

ISSN 1996-4536 (print) • ISSN 2311-0783 (on-line) • Біологічні Студії / Studia Biologica • 2019 • Том 13/№2 • С. 3-10 


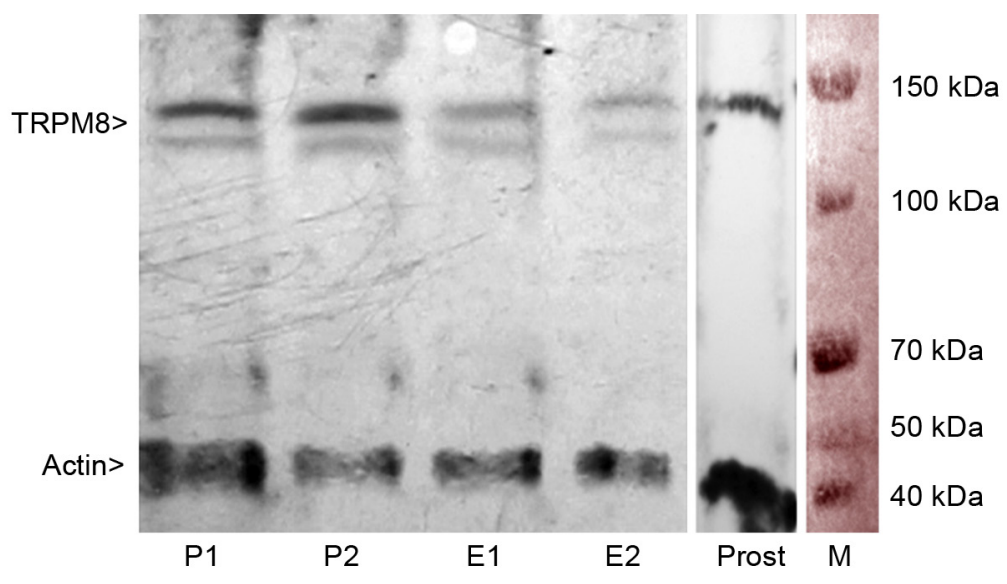

Fig. 5. Results of Western-blot analysis for determination of Trpm8 expression. Total protein of the prostatic (P1, P2) and epididymal (E1, E2) parts of vas deferens was studied by a standard immunoblotting. As a positive control, total protein extracted from rat prostate was used (Prost). M: Broad Range Protein Ladder stained on the membrane with Ponceau S

Рис. 5. Вестерн-блот для визначення наявності Trpm8 білка. Загальний білок простатного (P1, P2) та епідидимального (E1, E2) відділів сім'явивідних проток вивчали за допомогою стандартного імуноблоту. Як позитивний контроль використовували загальний білок простати щурів (Prost). M - маркер ваги білків Broad Range Protein Ladder, пофарбований на мембрані за допомогою барвника Ponceau S

\section{CONCLUSION}

Our current results show that a selected section of Trpm8 mRNA could be a subject for alternative splicing, with a removal of a fragment of approximately $45 \mathrm{bp}$ length in VD. This hypothesis of truncated mRNA resulting in a truncated Trpm8 protein could explain both the presence of immunohistochemical signal and Western-blot signal in VD rat tissue, as well as the absence of Trpm8 specific currents in isolated myocytes of rat VD observed previously [5]. The bioinformatic analysis of a selected sequence shows that the amplified fragment lies in the open frame region of Trpm8 mRNA, and corresponds to the 388-458 amino acid fragment of rat Trpm8 protein. UniProt entry Q8R455 for Trpm8 of $R$. norvegicus shows that the selected amino acid sequence is located within N-terminal domain of the Trpm8 protein. The N-terminal domain is the largest protein located in the cytoplasm. Studies done by Noyer and Bidaux teams show that Trpm8 mRNA isoforms such as Trpm8 $\alpha$ and Trpm8 $\beta$ an be found in human prostate cancer cells. They encode proteins sM8-6 (6 kDa) and sM8-18 (18 kDa). The annotated protein weight of both isoforms differs from one we observed in this work. However, these proteins are translated from splice isoforms of N-terminal domain, possibly observed in this study [4, 8]. Further work with this splice isoform of Trpm8 mRNA from rat VD is needed. This includes cloning and sequencing of the amplicon, and it will be a topic of our future research.

\section{ACKNOWLEDGMENTS AND FINANCIAL SUPPORT}

This research was partially funded by the National Academy of Sciences of Ukraine program "Biotechnology", Project No КП2016-1, received by prof. Y. Shuba.

ISSN 1996-4536 (print) • ISSN 2311-0783 (on-line) • Біологічні Студії / Studia Biologica • 2019 • Том 13/№2 • С. 3-10 
1. Artimo P., Jonnalagedda M., Arnold K., Baratin D., Csardi G., de Castro E., Duvaud S., Flegel V., Fortier A., Gasteiger E., Grosdidier A., Hernandez C., loannidis V., Kuznetsov D., Liechti R., Moretti S., Mostaguir K., Redaschi N., Rossier G., Xenarios I., Stockinger H. ExPASy: SIB bioinformatics resource portal. Nucleic Acids Research, 2012: 40(W1): W597-W603. [DOI: https://doi.org/10.1093/nar/gks400; PMID: 22661580; Google Scholar]

2. Behrendt H-J., Germann T., Gillen C., Hatt H., Jostock R. Characterization of the mouse coldmenthol receptor TRPM8 and vanilloid receptor type-1 VR1 using a fluorometric imaging plate reader (FLIPR) assay. Br J Pharmacol, 2004; 141(4): 737-745. [DOI: https://doi.org/10.1038/sj.bjp.0705652; PMID: 14757700; Google Scholar]

3. Belevych A.E., Zima A.V., Vladimirova I.A., Hirata H., Jurkiewicz A., Jurkiewicz N.H., Shuba M.F. TTX-sensitive $\mathrm{Na}^{+}$and nifedipine-sensitive $\mathrm{Ca}^{2+}$ channels in rat vas deferens smooth muscle cells. Biochimica et Biophysica Acta, 1999; 1419(2): 343-352.

[DOI: https://doi.org/10.1016/S0005-2736(99)00075-9; PMID: 10407085; Google Scholar]

4. Bidaux G., Beck B., Zholos A., Gordienko D., Lemonnier L., Flourakis M., Roudbaraki M., Borowiec A-S., Fernández J., Delcourt P., Lepage G., Shuba Y., Skryma R., Prevarskaya N. Regulation of activity of transient receptor potential melastatin 8 (TRPM8) channel by its short isoforms. J Biol Chem, 2012; 287(5): 2948-2962.

[DOI: https://doi.org/10.1074/jbc.M111.270256; PMID: 22128173; Google Scholar]

5. Boldyrev O.I., Sotkis H.V., Kuliieva I.M., Vladymyrova I.A., Filippov I.B., Skryma R., Prevars'ka N., Shuba I.M. Expression of the cold receptor TRPM8 in the smooth muscles of the seminal ejaculatory ducts in rats. Fiziolohichnyi Zhurnal, 2009; 55(5): 17-27. [PMID: 20095380; Google Scholar]

6. Filippov I.B., Vladymyrova I.A., Kuliieva I.M., Skryma R., Prevarskaia N., Shuba I.M. Modulation of the smooth muscle contractions of the rat vas deferens by TRPM8 channel agonist menthol. Fiziolohichnyi Zhurnal, 2009; 55(6): 30-40.

[PMID: 20201386; Google Scholar]

7. McKemy D.D., Neuhausser W.M., Julius D. Identification of a cold receptor reveals a general role for TRP channels in thermosensation. Nature, 2002; 416(6876): 52-58.

[DOI: https://doi.org/10.1038/nature719; PMID: 11882888; Google Scholar]

8. Noyer L., Grolez G.P., Prevarskaya N., Gkika D., Lemonnier L. TRPM8 and prostate: a cold case? Pflugers Archiv: European Journal of Physiology, 2018; 470(10): 1419-1429 [DOI: https://doi.org/10.1007/s00424-018-2169-1; PMID: 29926226; Google Scholar]

9. Pan Y., Thapa D., Baldissera L., Argunhan F., Aubdool A.A., Brain S.D. Relevance of TRPA1 and TRPM8 channels as vascular sensors of cold in the cutaneous microvasculature. Pflugers Archiv: European Journal of Physiology, 2017; 470(5): 779-786. [DOI: https://doi.org/10.1007/s00424-017-2085-9; PMID: 29164310; Google Scholar]

10. Peier A.M., Moqrich A., Hergarden A.C., Reeve A.J., Andersson D.A., Story G.M., Earley T.J., Dragoni I., Mclntyre P., Bevan S., Patapoutian A. A TRP channel that senses cold stimuli and menthol. Cell, 2002;108(5): 705-715.

[DOI: https://doi.org/10.1016/s0092-8674(02)00652-9 PMID: 11893340; Google Scholar]

11. Stothard $P$. The sequence manipulation suite: JavaScript programs for analyzing and formatting protein and DNA sequences. Biotechniques, 2000; 28(6): 1102, 1104.

[DOI: https://doi.org/10.2144/00286ir01; PMID: 10868275; Google Scholar]

12. Tsavaler L., Shapero M.H., Morkowski S., Laus R. Trp-p8, a novel prostate-specific gene, is up-regulated in prostate cancer and other malignancies and shares high homology with transient receptor potential calcium channel proteins. Cancer Res, 2001; 61(9): 3760-9. [PMID: 11325849; Google Scholar]

13. Weyer A.D., Lehto S.G. Development of TRPM8 Antagonists to Treat Chronic Pain and Migraine. Pharmaceuticals (Basel), 2017;10(2). pii: E37.

[DOI: https://doi.org/10.3390/ph10020037; PMID: 28358322; Google Scholar] 


\title{
ДВІ ІЗОФОРМИ ХОЛОДОВОГО РЕЦЕПТОРА ТrрМ8 У СІМ'ЯВИВІДНИХ ПРОТОКАХ ЩУРІВ
}

\author{
К. Гулак ${ }^{1 *}$, А. Кондрацький \\ ${ }^{1}$ Інститут фрізіології ім. О. О. Богомольця НАН України \\ вул. Богомольця, 4, Київ 01601, Україна \\ 2 Університет Лілля, вул. Paul Duez, 42, Лілль 59000, Франція \\ * Кореспондуючий автор: e-mail: ksenia@biph.kiev.ua
}

Trpm8 - це неселективний катіонний $\mathrm{Ca}^{2+}$-проникний іонний канал, що активується зниженням температури до $28^{\circ} \mathrm{C}$ та речовинами, що імітують холодове відчуття, зокрема, ментолом та іциліном. Trpm8 експресується у сенсорних нейронах, де його функція полягає в передачі температурних відчуттів, проте Trpm8 також експресується у внутрішніх органах, де температура тіла стабільно висока та не опускається нижче за $36^{\circ} \mathrm{C}$, що є набагато вищим за температуру активації Trpm8 каналу. Це дає підстави припустити, що Trpm8 може виконувати інші, крім терморегулюючих, функції, зокрема, брати участь у ноцицепції. мРНК Trpm8 експресується у сім'явивідних протоках — порожнистому м'язовому органі чоловічої статевої системи. Проте в попередніх роботах, зокрема, в наших, у міоцитах сім'явивідних протоків не було встановлено наявності струмів, характерних для Trpm8. Сім'явивідні протоки розташовані поза яєчками та складаються з гладеньком'язової тканини й епітеліального шару. Ці протоки активно скорочуються і транспортують сперму від яєчок до сім'явипорскувальних проток перед еякуляцією. Оскільки температура у сім'явивідних протоках стабільно висока, роль Trpm8, імовірно, полягає не в температурочутливості. Метою цього дослідження було проаналізувати експресію мРНК та білка Trpm8 у сім'явивідних протоках щурів і провести аналіз сплайс-варіантів цього транскрипту. Експресія гена Trpm8 була підтверджена на рівні мРНК, а Trpm8 білок виявлений за допомогою Western-блот аналізу. У тканині сім'явивідних протоків було виявлено коротші порівняно з класичною ізоформою Trpm8 мРНК і білок поряд із канонічною ізоформою. Ми ізолювали окремі гладеньком'язові клітини зі сім'явивідних проток і провели багатоклітинну полімеразну ланцюгову реакцію. Такий методичний підхід дає змогу позбутися забруднення зразків тканини неміоцитною мРНК, яка може потрапити у тканину, зокрема, з терміналей сенсорних нейронів, де Trpm8 експресується на високому рівні. Цікаво те, що в ізольованих міоцитах не встановлено наявності класичної Trpm8 мРНК, проте була наявна неканонічна ізоформа каналу. Ми припускаємо, що коротша ізоформа формується внаслідок альтернативного сплайсингу, і цим можна пояснити різницю функціонування Trpm8 у сім'явивідних протоках, а саме відсутність струмів, характерних для каналу Trpm8. Коротша ізоформа може мати вкорочений N-кінцевий домен білка Trpm8, що відповідає відомим білковим ізоформам Trpm8 у людини sM8-6 та sM8-18.

Ключові слова: Trpm8, холодовий рецептор, сплайс варіант, сім'явивідні протоки, міоцити, експресія генів

Одержано: 25.06.2019

ISSN 1996-4536 (print) • ISSN 2311-0783 (on-line) • Біологічні Студії / Studia Biologica • 2019 • Том 13/№2 • C. 3-10 